\title{
Demand-driven commercial whalewatching in Península Valdés (Patagonia): conservation implications for right whales
}

\author{
Mariana Rivarola*, Claudio Campagna ${ }^{+}$and Alicia Tagliorette ${ }^{\dagger}$ \\ Contacte-mail: mrivarola@ecocentro.org.ar
}

\begin{abstract}
One of the largest remaining populations of the southern right whale, Eubalaena australis, breeds along the coast of Península Valdés, in Argentine Patagonia. The area offers excellent opportunities for whalewatching because it is possible, with predictability, to have close-up views of animals of all ages. During 11 years, from 1987 to 1997 , more than 337,000 tourists took part in boat excursions to watch right whales. The demand increased during this period over 14 times from 5,214 tourists in 1987 to 73,726 in 1997 . From 1991 to 1994 , more than 8,000 boat trips were required to satisfy a demand of 125,000 people. Most whalewatching involved pregnant animals or mothers and calves that often attempted to avoid the boats. In 1997, whalewatching generated direct revenues of at least \$US 1 million in boat fees, and direct plus indirect revenues of over \$US 15 million (not including travel costs to Patagonia). The rapid growth of tourism in relation to whales has undisputed economic and public-awareness benefits but it is also raising concern about potentially detrimental effects on the animals. The lack of a management plan and of estimates of a tourist 'carrying capacity' allows customer demand to be the main driving force behind a commercial activity based on this vulnerable species.
\end{abstract}

KEYWORDS: RIGHT WHALE; WHALEWATCHING; SOUTHERN HEMISPHERE; SOUTH AMERICA; BEHAVIOUR; SUSTAINABILITY; BREEDING GROUNDS

\section{INTRODUCTION}

Whalewatching is one of the most rapidly growing and economically attractive tourist activities worldwide (Hoyt, 1992). It is also an incentive for the conservation of whales. If properly managed, whalewatching can benefit local economies, scientific research, educational purposes, public awareness, recreational activities and, ultimately, the whales themselves (IFAW Tethys and Europe Conservation, 1995).

Argentine Patagonia is one of the best places in the world to watch the depleted southern right whale (Eubalaena australis) with predictability and at close range (Payne, 1972a; b; 1976; 1986; Bastida and Lichtschein, 1981; Harris and García, 1986; Rivarola et al., 1995a; b; Campagna and Lichter, 1996). Individuals from one of the largest remaining populations of this species ( $c$ a 2,600 whales; IWC, 2001b) breed, from May to December, along the coast of Península Valdés (Whitehead et al., 1986; Payne et al., 1990). Until the 1970s, the existence of whales breeding in the waters around Península Valdés was known by few apart from the residents of the nearby coastal towns (Gilmore, 1969; Cummings et al., 1971; Garciarena, 1988). Today, whalewatching based on southern right whales has become the most important tourist attraction in Patagonia (Campagna et al., 1995; Rivarola et al., 1995a; b). The rapid growth of whalewatching has raised concerns about its effects on the animals almost from its beginning (Lichtschein and Bastida, 1983; Bastida, 1987; Rivarola et al., 1995a; b). While whalewatching is known to induce short-term behavioural changes in the target species (Watkins, 1986; Garciarena, 1988; Alverez Colombo et al., 1990; Arias et al., 1992), it is unknown whether this activity can adversely affect the long-term viability of such species (IFAW Tethys and Europe Conservation, 1995).

The aims of this study are to describe the trend in the demand for whalewatching, evaluate the ability of the industry to satisfy that demand, estimate the economic value of the activity and evaluate the short-term effects of whalewatching on the behaviour of whales. The paper expands and updates the information provided by Rivarola et al. (1995a; b) and summarises an unpublished technical report requested by the United Nations Environment Programme (UNEP) on whalewatching in Argentina (Campagna et al., 1995). The 11 year period covered by this report (1987-1997) represents virtually the entire history of whalewatching in Patagonia. This study shows that whalewatching has not only important economic effects for Patagonia but also largely unknown potential effects upon the conservation of the southern right whale in the southwest Atlantic Ocean.

\section{BACKGROUND INFORMATION}

\section{Biological aspects}

The world population of southern right whales had been estimated at 4,000 individuals, divided into 3-4 sub-populations (Klinowska, 1991). More recent theoretical estimates of abundance levels yield 7,571 individuals, divided into 11 breeding units (IWC, 2001b). Coastal Patagonia is one of the most important places for right whale reproduction in the southwest Atlantic (Payne, 1972a; b; 1976; 1986; 1994; Bastida and Lichtschein, 1981; 1984; Harris and García, 1986; Payne et al., 1990). In 1986, there were an estimated 1,200 southern right whales in the population that breeds off the coast of Península Valdés (Whitehead et al., 1986; Payne et al., 1990). This population was growing at a rate of approximately $7.1 \%$ per year (Payne et al., 1990). Current estimates for the Argentine breeding unit are of 2,577 animals (IWC, 2001b).

Right whales breed during the Southern Hemisphere winter and spring in two protected Patagonian bays, Golfo Nuevo and Golfo San José, and along the outer coast of Península Valdés (Fig. 1; Payne, 1972a; b; 1976; 1986; 1994; Payne and Rowntree, 1984). The first adults arrive in

\footnotetext{
* Fundación Patagonia Natural, 9120 Puerto Madryn, Argentina and Administración de Parques Nacionales.

+ Centro Nacional Patagónico (CONICET), 9120 Puerto Madryn, Argentina.

+ Organismo Provincial de Turismo de Chubut, Rawson, Argentina and Universidad Nacional de la Patagonia Austral.
} 


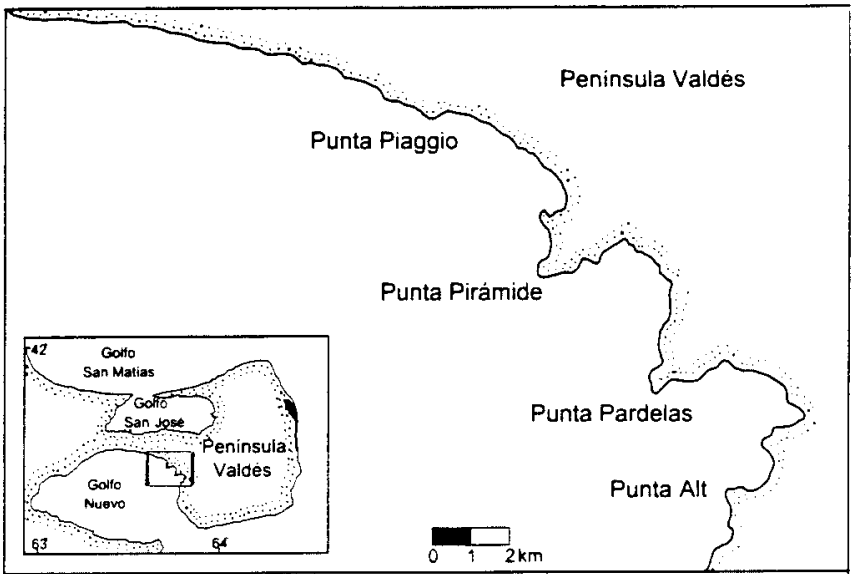

Fig. 1. Map of the study area.

April and May and increase in number until the height of the season, between September and October. Only a few whales remain in the area until December (Payne, 1986).

A long-term demographic and behavioural study conducted in Patagonia had resulted in the identification of 1,223 individuals by 1990 , based on natural markings (Payne et al., 1983; 1990; Cooke et al., 2001). These records, compiled over almost three decades, show that only a fraction of the population is found each breeding season off the coast of Península Valdés. Adult females tend to return to the area only during the years that they give birth, and most females calve every three years. About 50 calves are born each year in the area (Payne et al., 1983; Whitehead et al., 1986).

\section{Whalewatching in Argentina}

Whalewatching is a prominent economic activity in Argentina but only in Patagonia (Garciarena, 1988). The waters surrounding Península Valdés offer whalewatchers close-up views of mothers and calves, and individuals of various ages and reproductive status (Payne, 1972b; 1976; 1994; Bastida and Lichtschein, 1981; 1984; Harris and García, 1986). Right whales are found throughout the year, except for the period January-March. Animals tend to stay within $100 \mathrm{~m}$ of the coast and are often seen as close as $5-10 \mathrm{~m}$ from the shore.

This situation has promoted a rapidly growing whalewatching industry based in the small town of Puerto Pirámide, on the shores of Golfo Nuevo (Fig. 1). Whalewatching began commercially in the early 1970s, when local boat operators took small groups of people, mostly foreigners, in small inflatable boats with outboard engines, to watch whales (Lichtschein and Bastida, 1983; Bastida, 1987). There are no data regarding the number of people that bought boat tickets to watch whales until 1987. Estimated numbers of tourists range from a few hundred in the 1970 s and early 1980 s to nearly 5,000 people per year in the mid-1980s.

\section{Legal protection of whales}

At a national level, the Argentine Congress has declared southern right whales a 'Natural Monument' (law 23094 of 1988). This status applies in territorial waters and does not apply to whales in international waters or even in waters under the jurisdiction of local Provincial governments. None of the Patagonian coastal provinces has ratified this law for their respective territories.
At a Provincial level, the Government of the Province of Chubut declared Golfo San José a 'Provincial Marine Park' (law 1238 of 1975) to protect one of the most important breeding areas of the right whale in South Atlantic waters. This law was later modified (Decree 1713 of 1979) changing the protected status of the Gulf to one of management for multiple use. Whalewatching takes place within the jurisdiction of Chubut Province; therefore, regulations to manage the activity and protect the whales are the responsibility of the Provincial rather than national Government. The first regulations to protect whales encountered during whalewatching trips date from 1984 (law 2381). This law defines:

(1) some protected areas along the coast where whalewatching is not allowed (since then, new areas have been added by law 4098 of 1995);

(2) minimum permitted distance of boats to whales $(100 \mathrm{~m}$ with engines on, $50 \mathrm{~m}$ with engines off);

(3) minimum permitted distance of divers to whales $(100 \mathrm{~m})$

(4) restriction of number of boats around a whale (only one at a time); and

(5) some manoeuvres to be considered as harassment (e.g. driving the boat in circles around the whale, chasing whales).

The enforcement of restrictions on whalewatching activities is the responsibility of two agencies: the Organismo Provincial de Turismo of Chubut (for the protection of the whales), and the Prefectura Naval Argentina (for safety on board). However, regulations are difficult to enforce and manoeuvres that may qualify as harassment according to Provincial regulations are a regular component of whalewatching trips. Despite this, no serious boat accidents have been formally reported or documented since the activity began and no strong evidence exists of whale injuries caused during whalewatching trips conducted by licensed professionals. Boat drivers are all local residents and experienced navigators.

\section{General setting}

Besides tourism related to whales, the area is facing increasing development of many kinds. Puerto Madryn, on the shores of Golfo Nuevo, is one of the fastest growing cities in coastal Patagonia, with a population of about 45,000 inhabitants by the mid-1980s. It lies along the western coast of the Gulf and releases large quantities of sewage into its waters. An aluminium factory and several fish processing plants generate a considerable amount of shipping traffic and an unknown level of pollution.

Golfo San José was previously the only place set aside as a refuge for right whales (see above). However, the present legal status of the Gulf allows for the development of economic initiatives. For example, in 1992, aquaculture began on a small scale in the Gulf, involving ropes suspended from buoys in prime right whale habitat. This has occurred despite the fact that studies of northern right whales show that they have difficulty avoiding ropes; for example Knowlton and Kraus (2001) report that of 50 animals either severely injured or killed, 26 had suffered injuries from entanglements.

\section{METHODOLOGY}

\section{Estimating demand}

Demand was defined as the number of people that purchase whalewatching tickets. Whalewatching was defined as the observation of whales from boats. Information on the 
number of tourists buying whalewatching tickets, the numbers of whalewatching trips and the revenue derived from this commercial activity were obtained from several different sources: the Organismo Provincial de Turismo de Chubut (Tourism Agency of Chubut Province), Prefectura Naval Argentina (Coastguards) and the private companies that provide the services. Whalewatching records are kept by the Prefectura Naval Argentina but are reported by the companies that provide the service. Records list boat departure times, number of passengers, names of the companies and skippers of the boats for every excursion leaving Puerto Pirámide.

\section{Calculating the income for the 1994 season}

The economic aspects of whalewatching in Península Valdés were calculated based on the 1994 season, a year when the activity was strictly controlled and the economic data were most reliable. Income from boat fees was estimated based on an average cost of \$US20 per person for a whalewatching trip. The upper limit of the cost per trip is fixed by contract between the companies that provide the services and the Provincial Government that regulates the activity. A $10 \%$ deduction from boat fees is paid as tax to the Provincial Government. Boat fees have remained more or less constant during the last five years (from \$US15-25 in 1998).

Direct and indirect revenues included income from boat fees plus room and board for two full days (\$US40 per day per person), souvenirs (10\% of total receipts), the cost of travelling to Península Valdés from Puerto Madryn and entrance fees to Península Valdés. The calculation of revenue does not include travel costs to Puerto Madryn.

For comparative purposes, an estimate of direct and indirect income was calculated for the 1997 season. Numbers were based on the taxes paid by the companies providing the whalewatching services.

\section{Whale behaviour in response to boats}

General observations of the interaction between whales and boats were conducted from vantage points on the cliff tops at Puerto Pirámide, Península Valdés, during the 1993-1994 whalewatching season. Observations covered the coastal area between Punta Piaggio (42 32 'S, $64^{\circ} 28^{\prime} \mathrm{W}$ ) and Punta Alt (42 $41^{\prime}$ 'S, 64 ${ }^{\circ} 16^{\prime} \mathrm{W}$ ) (Fig. 1). Most boats operated within $1-2 \mathrm{~km}$ of Puerto Pirámide and were easily observed from the cliffs.

\section{Animal counts}

An estimate of the number of whales present in the study area was obtained by counts made twice a day throughout the season, from the highest point at Puerto Pirámide Wildlife Reserve (located about $3 \mathrm{~km}$ from the port of departure of the whalewatching boats). Each count took about 30 minutes and differentiated mothers and calves from adults (solitary or in groups).

\section{Boat activity}

Interactions between boats and whales were described for 116 trips. The following boat manoeuvres were recorded.

(1) Direct approach: the boat moved from the port or some point at sea in a straight line towards a whale.

(2) Encircling: the boat moved around the whale or group of whales within a distance of $10-100 \mathrm{~m}$.

(3) Chasing: the boat moved behind a whale or parallel to it, increasing its speed when the whale increased its distance.
These three boat manoeuvres are forbidden by the law that regulates whalewatching in Argentina (see above). We refer to them as high impact manoeuvres and compared the response of whales during trips in which none of the manoeuvres were used $(n=20)$ to others in which all three were used in the same trip $(n=45)$.

Whale activity

The following behaviours were recorded.

(1) Approach: the whale approached a boat and remained at less than one body length from it for several minutes.

(2) Moving away: the whale moved away from a boat, swimming either at the surface or underwater.

Target of whalewatching

A total of 565 scan samples were recorded daily every 30 minutes for seven hours during the 1993 season. This enabled us to assess the proportion of whalewatching trips in the study area made either on mother-calf pairs or on individuals without calves. Boats typically approached more than one whale during trips that lasted from about 45-100min. Most boats usually remained with the same whale for less than 30 minutes. Therefore, the 30 minute period between each successive scan sample allowed for some changes to take place (e.g. beginning/end of some trips, change of whalewatching site). This avoided the same event being recorded several times.

\section{Interactions between boats and whales}

Scan samples were also used to estimate the proportion of time during which one or more boats were watching whales. Information on the manoeuvres of boats and the behavioural response of whales to such manoeuvres was recorded as a serial record for 116 whalewatching trips during 1993. A 'whalewatching trip' was defined as the period between the time the target boat left port until the time it returned. Each serial record consisted of a detailed chronological description of the main events that occurred from boat departure to its return about one hour later. When more than one whale was approached by a boat during a trip, records of interactions were differentiated for each individual whale or mother-calf pair.

\section{RESULTS}

Demand and efficiency of the commercial activities

At least 337,685 tourists engaged in whalewatching trips during the 11 years considered in this study (June-December 1987-97, Fig. 2). The demand for boat trips to watch whales increased immensely for that period. In 1997, at least 73,726 tourists watched whales from boats (versus 5,214 for 1987).

The monthly distribution of the demand varied during the season, reaching a maximum in October (Fig. 3). Between 27 and $33 \%$ of the annual demand was concentrated in this month. The peak number of tourists coincided with the maximum number of whales in the calving area (Figs 3 and $4)$. The number of boat trips per month was correlated with the demand for the same period (Fig. 5; Kendall's T for the 1994 season chosen as an example $=3.15, P<0.05$, $n=7)$.

The number of boat trips per season, and thus the exposure of whales to disturbance and potential accidents, was higher during most seasons than an optimum number that could have satisfied the same demand (Table 1). The mean number of tourists per trip in the early 1990s was $12-13$, considerably 


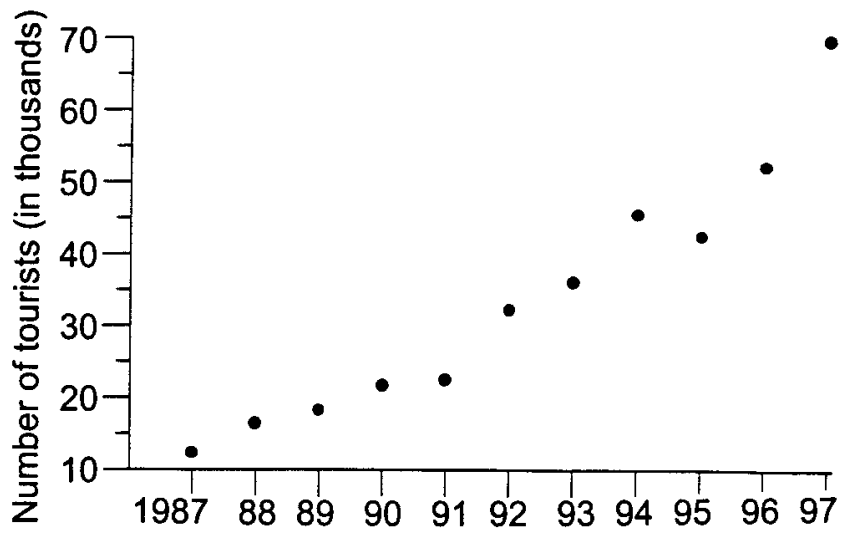

Fig. 2. Trends in the demand for whalewatching at Península Valdés for the period 1987-97.

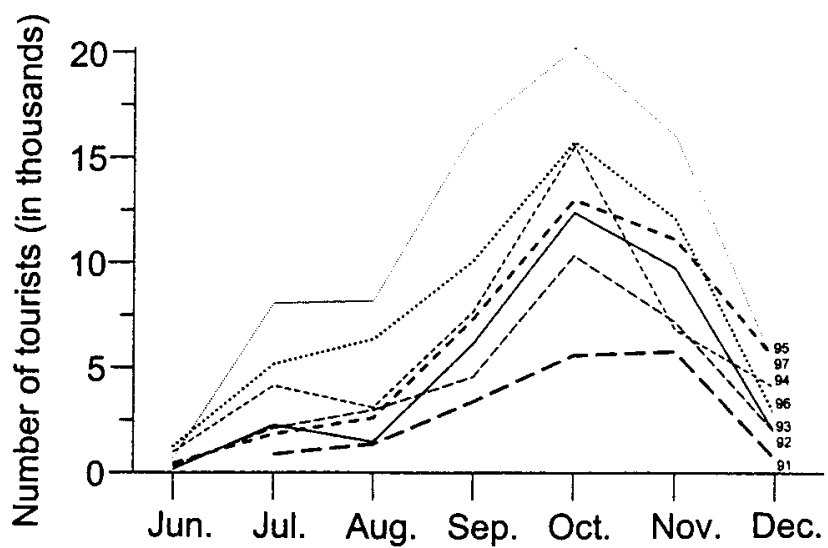

Fig. 3. Number of tourists per month for seven whalewatching seasons.

less than the average boat capacity for those years of 20 passengers per boat. In 1991, $43 \%$ of trips carried half the vessel's capacity; in 1992, this figure was $35 \%$. This means that there were $\mathrm{ca} 1,400$ trips in which boats took 10 or fewer passengers. In only $22 \%$ of 2,209 trips for 1992 were the boats filled to capacity. In 1993, a restructuring of the companies reduced the total number of boat trips, despite an increase in demand by approximately 5,000 compared with the previous year. However, an increase in the number of whalewatching companies in 1994 from three to six reduced efficiency to $61 \%$ of the optimum, the same as in 1991. In 1994, operating at maximum efficiency, the companies could have serviced about 5,000 people per day in tours that

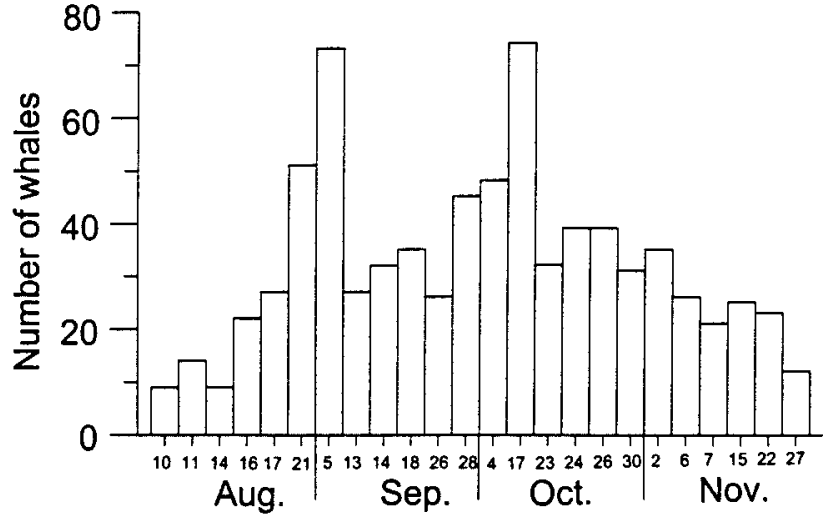

Fig. 4. Maximum number of whales counted in the study area.

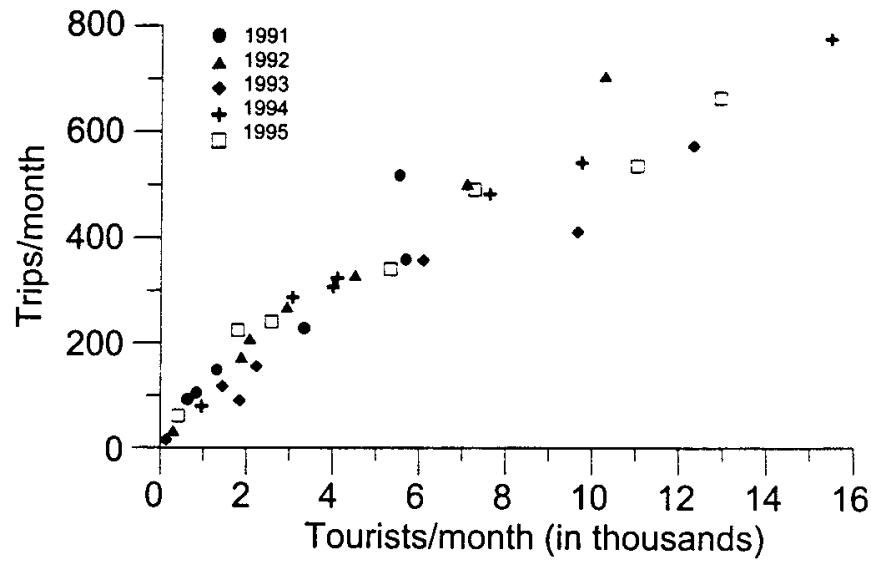

Fig. 5. Whalewatching trips per month as a function of the number of tourists.

lasted about one hour. More than 600 tourists could have been engaged in whalewatching trips at any given time. However, efficiency during that year was only $80 \%$ of that for 1993 (Tables 1 and 2).

\section{Target of whalewatching}

Mothers and calves were the selected target for whalewatching in $49 \%$ of 565 scan samples recorded in 1993. At the beginning of the season, when most births had yet to occur, single whales were approached more frequently than later in the season. Towards the end of the season, all approaches were targeted at the few mothers and calves that still remained in the area (Fig. 6).

Table 1

Progression of tourist demand and whalewatching trips for the period 1991-94 (data not available for other seasons). In 1993 whalewatching companies worked cooperatively and most boats filled their capacity before leaving port.

\begin{tabular}{|c|c|c|c|c|c|}
\hline Variable & 1991 & 1992 & 1993 & 1994 & Total (1991-94) \\
\hline No. of tourists & 17,446 & 29,121 & 33,772 & 44,987 & 125,326 \\
\hline No. of whalewatching trips & 1,435 & 2,208 & 1,706 & 2,774 & 8,123 \\
\hline Maximum number of tourists allowed per boat per trip & 20 & 20 & $20^{2}$ & see Table 2 & $20-80$ (see Table 2$)$ \\
\hline Mean \pm 1 SD number of tourists per trip & $12.0 \pm 5.8$ & $13.2 \pm 5.8$ & $19.8 \pm 8.4$ & $16.0 \pm 3.4$ & $15.3 \pm 3.5$ \\
\hline Range & $1-20$ & $1-20$ & $\begin{array}{l}1-20 \\
1-40^{2}\end{array}$ & $1-80$ & $1-80$ \\
\hline Efliciency of industry measured against the 1993 season $^{1}$ & $60 \%$ & $66 \%$ & $100 \%$ & $80 \%$ & $77 \%$ \\
\hline Number of expected trips if boats had been filled to capacity & 869 & 1,453 & 1,346 & 1,693 & 5,361 \\
\hline Observed efficiency as a percent of optimum efliciency ${ }^{3}$ & $60 \%$ & $66 \%$ & $79 \%$ & $61 \%$ & $66 \%$ \\
\hline
\end{tabular}

Calculated as a rate of the mean number of tourists per boat trip relative to 1993 (e.g. $12.0 / 19.8=60 \%$ ).

${ }^{2}$ A larger boat for 40 passengers was used during the last months of the 1993 season.

${ }^{3}$ Calculated by dividing the optimum number of trips (i.e. trips that would have occurred if boats were filled to capacity) by the observed number of trips per season. 
Table 2

Number of boats and boat capacity (in brackets) during the 1991-1994 seasons. In 1994 only six companies were authorised for whalewatching activities, two companies ran tours that were not aimed at whalewatching but that approached whales on an opportunistic basis.

\begin{tabular}{lcccc}
\hline Type of vessel & 1991 & 1992 & 1993 & 1994 \\
\hline Number of companies & $5-6$ & 6 & 3 & 8 \\
Boats $(\geq 20)$ & 11 & 12 & 5 & 7 \\
Boats $(\geq 40)$ & 0 & 0 & 1 & 2 \\
Boats $(\geq 90)$ & 0 & 0 & 0 & 1 \\
Catamarans $(\mathrm{ca} 80)$ & 0 & 0 & 0 & 3 \\
Sail boats & 0 & 0 & 0 & 1 \\
Catamarans $(\mathrm{ca} 120)$ & 0 & 0 & 0 & 1 \\
Total vessels & 11 & 12 & 6 & 15 \\
\hline
\end{tabular}

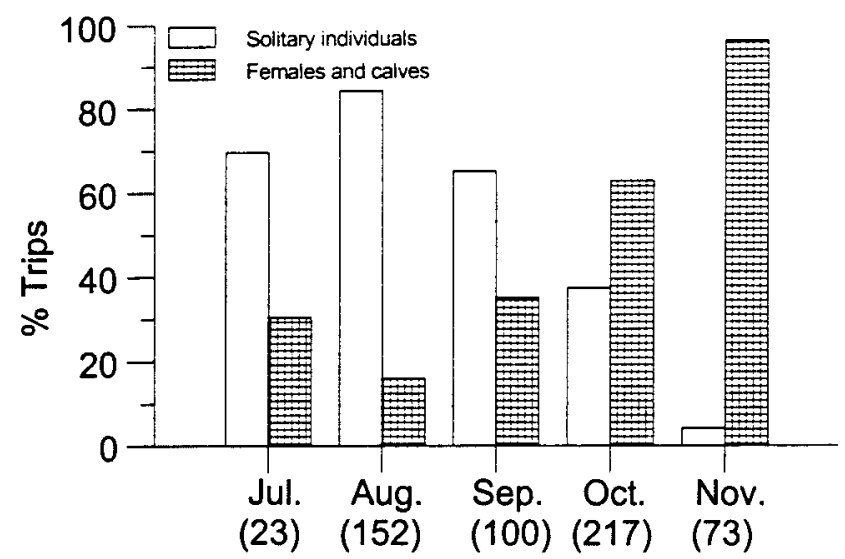

Fig. 6. Proportion of solitary individuals and mother-calf pairs exposed to whalewatching per month. Number of trips is given in parentheses.

\section{Economic aspects}

Total direct and indirect revenues for 1994 were \$US 10.3 million. This revenue includes boat fees, travel costs, room and board, souvenirs and entrance fees to the Península. In 1997, the total income from boat fees was estimated at more than \$US 1 million and total direct and indirect revenues over \$US 15 million (not including travel costs to Patagonia).

\section{Short-term effects of whalewatching on whale behaviour}

For $81 \%$ of the time that an animal or a group of whales were exposed to whalewatching, only one boat at a time approached the target (based on 565 scan samples taken every 30 mins). For $19 \%$ of the whalewatching time, the animal or group was approached by two or more boats simultaneously.

From 116 observed whalewatching trips, boats intercepted (direct approach: $49 \%$ of the trips), encircled $(49 \%)$ or chased $(54 \%)$ whales at least once during the trip. These manoeuvres occurred up to nine times during the 45-100 minutes that a trip lasted. In only $17 \%$ of the 116 trips one of the high impact manoeuvres occurred during the approach; however, in 39\% all three manoeuvres took place within one trip.

These manoeuvres affected the behaviour of the whales, although the response of the animals was not consistent. Some whales approached the boats even when all three high impact manoeuvres occurred during the interactions (Table 3). However, when direct approach, encircling and chasing occurred during the same whalewatching trip, whales moved away from the boats significantly more frequently than: (a) approaching boats (Mann-Whitney $U=-3.98 ; P<0.05$; Table 3); and (b) when those manoeuvres were absent (Mann-Whitney $U=-4.39, \mathrm{P}<0.05$ ).

\section{Table 3}

Mean ( \pm standard error) number of times per trip when one or more whales approached or moved away from a whalewatching boat as a function of the occurrence of high impact (HP) manoeuvres (i.e. direct approach, encircling and chasing). Data are for observations in which all three manoeuvres occurred during the same trip. Total number of trips is in parentheses.

\begin{tabular}{lcc}
\hline & Approach & Move away \\
\hline With HP manoeuvres & $1.95 \pm 0.45$ & $4.76 \pm 0.42$ \\
& $(n=20)$ & $(n=25)$ \\
Without HP manoeuvres & $2.35 \pm 0.40$ & $1.85 \pm 0.27$ \\
& $(n=20)$ & $(n=20)$ \\
\hline
\end{tabular}

\section{DISCUSSION}

Almost 30 years since the first whalewatchers pioneered the activity, southern right whales have become the most important tourist attraction along $\mathrm{ca} 3,000 \mathrm{~km}$ of coastal Patagonia (Campagna et al., 1995; Rivarola et al., 1995a; b). Placed in an international perspective, whalewatching in Argentina has grown to levels similar to those in Japan, Mexico, Australia and the United Kingdom (Campagna et al., 1995).

Due to the local, national and international interest that whales generate, whalewatching in this area is likely to continue to increase. A prediction that, by the end of this century, over 150,000 tourists per year will be buying boat tickets to watch whales in this area, may even be an underestimate. The activity is a multi-million dollar industry and our figures are a conservative estimate of its economic importance. Virtually all (91\%) of the 82,000 or more tourists that visited Península Valdés during the period June-December 1997 were involved in whalewatching. It is clear that there is an expanding demand, focused on the whales, which did not exist a decade ago. 'Ecological' tourism is today one of the fastest growing sources of income and employment for the Province of Chubut (Rivarola et al., 1995a).

Since its beginning as an organised commercial activity, whalewatching has been driven by demand. Management decisions have not taken into account the possibility of adverse changes in the behaviour and distribution of whales. The tourist 'carrying capacity' of whalewatching has not been estimated but, as stated by Hoyt (1992), it may already have been reached. ${ }^{1}$ There have been several attempts to improve management which ended in statements of good intent but no serious commitment from any of the involved parties. In 1997, the Provincial Government officially requested a management plan for Península Valdés that would include updated regulations for whalewatching. It is not known if this initiative will be the starting point of a new approach.

Short-term effects on whale behaviour and distribution Perhaps the best way to evaluate the impact of whalewatching may be to show the effect of the activity on the survival, breeding success and distribution of individual whales (IFAW Tethys and Europe Conservation, 1995). To date, however, there are no such comprehensive data for the

\footnotetext{
1 Numbers of visitors in 1998 and 1999 were 79,481 and 74,512, respectively.
} 
southern right whales of Patagonia. An important change in distribution that involved a traditional whalewatching area was noted in 1994. The number of whales around Puerto Pirámide peaked in early September $(n=73$ animals on 5 September 1994). At the same time, about 50 mothers and calves were found at El Doradillo, 30-40km west of Puerto Pirámide, towards the city of Puerto Madryn. El Doradillo had not previously been recorded as such an important calving location. An average for 1991-1997 reveals that fewer than half the number of animals seen at Puerto Pirámide concentrated at peak season at El Doradillo (Rowntree et al., 2001). The 1994 whalewatching activity was consequently targeted at the few animals that remained around Puerto Pirámide, with sometimes up to six boats around the same mother-calf pairs. However, changes in calving areas have been previously recorded for the waters around Península Valdés with no apparent connection to human activities (Payne et al., 1990). However, the occupation of this 'new' coastal area still persists at a level of about ten mother-calf pairs for 1997 (Carribero, 1998; Carribero, pers. comm.).

At present, our knowledge of the impact of whalewatching on the behaviour of right whales is limited to a description of general indicators of potential negative effects. The short-term response of southern right whales to the proximity of boats in Patagonia has been described several times during the last decade. In the early 1980s, it was observed that some whales avoided boats with outboard engines, but some whales seemed to be attracted to them (G. Harris and C. García, unpublished report to the Government of the Province of Chubut). The first study to quantify the effects of whalewatching on whale behaviour was conducted in the mid-1980s based on theodolite readings. This work consisted of descriptions of changes in the behaviour and speed of whales that could be attributed to the presence of boats (Garciarena, 1988; Alverez Colombo et al., 1990; Arias et al., 1992, results summarised by the authors in Campagna et al., 1995; IWC, 2001b). It was found that the mean swimming speed of solitary individuals and groups other than mother-calf pairs was faster within the whalewatching area of Golfo Nuevo than at Golfo San José. However, the speed of mother-calf groups did not vary significantly between the two, perhaps because young calves limit the mothers' swimming speed; if a mother increases her speed to avoid a boat, the calf could be left behind. Swimming behaviour was also less erratic at Golfo Nuevo and whale reaction to the presence of boats varied as a function of the stopping distance of the boat. Our data on the reaction of whales to approaching boats reinforces these results, and also shows that whales move away from boats that are encircling or following them as well as from boats that approach them directly.

Since the right whale is a long-lived species with a very low reproductive rate, it will be difficult to obtain information over a short time on the effects of whalewatching on survival and breeding. In the meantime, when considering whether whalewatching is harmless to whales, results from pilot impact studies should encourage a more cautious attitude. Whalewatching trips in this area are aimed at individuals that are in the most important stages of their biological cycles (pregnant females, mothers with calves, newly born calves, mating animals). Policy-makers must rely on the precautionary principle and management decisions must be based on the available circumstantial evidence. A step-wise introduction of permits, with regular feedback from population monitoring, would seem a viable approach to sustainable management.

\section{Changing attitudes}

The attitude of government officials and entrepreneurs responsible for promoting and conducting whalewatching activities must be shifted towards a more conservative approach. Efforts to sell dramatic whalewatching experiences, for example, with whales breaching a few metres away from boats (a sign that the boat may be disturbing the whale) and people touching whales (against the law), should be changed to the promotion of whalewatching as a peaceful, respectful and fascinating activity.

Attitudes towards whalewatching are often based on the assumption that clients will only be satisfied by being close to the animal. As companies compete to attract tourists, if one boat closely approaches a whale, the others are obliged to do so as well. Therefore, the experience is often limited to seeing whales in close proximity. The need to satisfy an uninformed demand is indirectly conveyed, rather than the need to respect the animal.

\section{Regulations}

Most regulations issued by the Province of Chubut are similar in essence and content to those affecting whalewatching in other parts of the world (Campagna et al., 1995). If properly enforced, some of these regulations would improve the quality of management in relation to conservation. Priority should be given to maintaining current reserves and setting aside new marine reserves in critical right whale habitat, such as the entire area of Golfo San José and the main calving areas of Golfo Nuevo.

More precisely, present regulations could be improved as follows.

(1) Whalewatching boats should take a qualified guide on board to improve the educational experience.

(2) Protected calving areas should incorporate new areas that have not previously been safeguarded from disturbance.

(3) Navigation should not be allowed in calving areas early and late in the season. The length of the whalewatching season may have to be shortened to decrease potential harassment of the first females arriving at the calving area and the last leaving it.

(4) Consideration should be given to redefining the legal status of Golfo San José, currently a multi-purpose area, as a Marine Park devoted to, among other things, the protection of whales.

Long-term study of the basic biology of the species, data from well-designed studies of the impact of human activities on the whales, and the commitment of Patagonian coastal communities to prevent further degradation of prime right whale habitat should give the southern right whale an opportunity to continue its recovery. It will also ensure the continuity of an industry that has a strong educational potential and that may protect right whales against commercial activities. However, unregulated, unlimited numbers of people approaching a few whales hundreds of times, in what would otherwise be a calm, peaceful environment for calving and breeding, is a clear recipe for unsuccessful management.

\section{ACKNOWLEDGEMENTS}

This paper has a precedent in a report made possible by the Marine Mammal Action Plan of the United Nations Environment Programme (UNEP). We wish to thank M. Borobia, at the time at the Nairobi Office of UNEP, for encouraging and supporting the preparation of that report. 
We are particularly thankful to P. Best and C. Carlson for reviewing a previous version of this paper; P. Lozano (Organismo Provincial de Turismo de la Provincia del Chubut) for providing information which helped us to estimate the economic importance of whalewatching; W. Conway (Wildlife Conservation Society), P. and G. Harris (Fundación Patagonia Natural), A. Lichter (Ecocentro Puerto Madryn), V. Rowntree (Whale Conservation Institute, WCI), R. Payne (WCI) and J. Seger (University of Utah) for helpful discussion during the preparation of the manuscript; and M. Lanfiutti, A. Pirronitto, S. Cévoli, R. Gonzalez and A. Carribero for invaluable field assistance. This study was partially supported by the Patagonian Coastal Zone Management Plan (Global Environmental Facility-Fundación Patagonia NaturalWildlife Conservation Society) and the Administración de Parques Nacionales of Argentina. Logistic support and information to accomplish this study were provided by the Organismo Provincial de Turismo de la Provincia del Chubut, Consejo Nacional de Investigaciones Científicas y Técnicas de la República Argentina and Prefectura Naval Argentina.

\section{REFERENCES}

Alvarez Colombo, G.L., Arias, A.M. and Garciarena, A.D. 1990. A possible effect of whale watching on right whales (Eubalaena australis). IV Reunión de Trabajo de Especialistas en Mamíferos Acuáticos de América del Sur, Valdivia, Chile [Abstract].

Arias, A., Alvarez Colombo, G. and Garciarena, D. 1992. Observaciones de reacciones a corto plazo en ballenas francas, Eubalaena australis, ante el acercamiento de embarcaciones turísticas. Resúmenes de la V Reunión de Trabajo de Especialistas en Mamíferos Acuáticos de América del Sur.

Bastida, R. 1987. La ballena franca austral: un recurso turístico peculiar. Revista Patagónica 6(29):24-8.

Bastida, R. and Lichtschein, V. 1981. La Ballena Franca Austral. Fauna, Argentina 25.

Bastida, R. and Lichtschein, V. 1984. Informe preliminar sobre los estudios de la Ballena Franca Austral, Eubalaena australis, en la zona de la Península Valdés (Chubut, Argentina). Rev. Mus. Argent. Cienc. Nat. 'Bernardino Rivadavia' Inst. Nac. Invest. Cienc. Nat. Zool. 23:197-209.

Campagna, C. and Lichter, A. 1996. Las Ballenas de la Patagonia. Ensayos sobre la Biología y la Conservación de la Ballena Franca Austral. Emecé Editores, Buenos Aires. 159pp.

Campagna, C., Rivarola, M.M., Greene, D. and Tagliorette, A. 1995. Watching southern right whales in Patagonia. Report for the Marine Mammal Action Plan of United Nations Environment Program. 95pp. [Available from: customerservices@earthprint.co.uk].

Carribero, A.A. 1998. Clasificación y caracterización de los grupos de ballenas francas en la playa El Doradillo. Tesis de Licenciatura. Facultad de Ciencias Naturales. Universidad Nacional de la Patagonia, San Juan Bosco. 42pp.

Cooke, J.G., Rowntree, V. and Payne, R. 2001. Updated estimates of demographic parameters for southern right whales (Eubalaena australis) observed off Península Valdés, Argentina. J. Cetacean Res. Manage. (special issue) 2:125-132.

Cummings, W.C., Fish, J.F., Thompson, P.O. and Jehl, J.R. 1971. Bioacoustics of marine mammals of Argentina: R/V Hero cruise 71-3. Antarct. J. US. 6:266-8.

Garciarena, D. 1988. The effects of whalewatching on right whales in Argentina. Whalewatcher 22(3):3-5.

Gilmore, R.M. 1969. Populations, distribution, and behavior of whales in the western South Atlantic: cruise 69-3 of R/V Hero. Antarct. J. US. 4(6):307-8.
Harris, G. and García, C. 1986. La Ballena Franca Austral. Editorial Golfo Nuevo, Puerto Madryn. 84pp.

Hoyt, E. 1992. Whale watching around the world. A report on its value, extent and prospects. Int. Whale Bull. 7:1-8.

IFAW Tethys and Europe Conservation. 1995. Report on the Workshop on the Scientific Aspects of Managing Whale Watching. Montecastello di Vibio, Italy 30 March-4 April 1995. 40pp. [Available from: info@ifaw.org].

International Whaling Commission. 2001a. Report of the Workshop on Status and Trends of Western North Atlantic Right Whales. J. Cetacean Res. Manage. (special issue) 2:61-87.

International Whaling Commission. 2001b. Report of the Workshop on the Comprehensive Assessment of Right Whales: A worldwide comparison. J. Cetacean Res. Manage. (special issue) 2:1-60.

Klinowska, M. (ed.). 1991. Dolphins, Porpoises and Whales of the World. The IUCN Red Data Book. IUCN, Gland, Switzerland and Cambridge, UK. viii + 429pp.

Knowlton, A. and Kraus, S. 2001. Mortality and serious injury of northern right whales (Eubalaena glacialis) in the western North Atlantic Ocean. J. Cetacean Res. Manage. (special issue) 2:193-208.

Kraus, S.D. 1990. Rates and potential causes of mortality in North Atlantic right whales (Eubalaena glacialis). Mar. Mammal Sci. 6(4):278-91.

Lichtschein, V. and Bastida, R. 1983. Whale watching in Argentina. Paper WA/SP/E1 presented to the co-sponsored Conference on the Non-Consumptive Utilization of Cetacean Resources, June 1983, Boston, Mass. (Unpublished). 4pp. [Available from the Office of this Journal].

Payne, R. 1972a. Report from Patagonia: the Right Whales. New York Zoological Society, New York. 6pp.

Payne, R. 1972b. Swimming with Patagonia's right whales. Natl. Geogr. 142:567-87.

Payne, R. 1976. At home with right whales. Natl. Geogr. 149(3):322-39.

Payne, R. 1986. Long term behavioral studies of the southern right whale (Eubalaena australis). Rep. int. Whal. Commn (special issue) 10:161-7.

Payne, R. 1994. Among whales. Nat. Hist. (January Issue):40-6.

Payne, R. and Rowntree, V.J. 1984. Southern Right Whales, A Photographic Catalogue of Individual Whales Seen in the Waters Surrounding Península Valdés, Argentina. Fundacion Alfredo Fortabat, Buenos Aires, Argentina. 77pp.

Payne, R., Brazier, O., Dorsey, E.M., Perkins, J.S., Rowntree, V.J. and Titus, A. 1983. External features in southern right whales (Eubalaena australis) and their use in identifying individuals. pp. 371-445. In: R. Payne (ed.) Communication and Behavior of Whales. AAAS Selected Symposia Series 76. Westview Press, Colorado. xii+643pp.

Payne, R., Rowntree, V., Perkins, J.S., Cooke, J.G. and Lankester, K. 1990. Population size, trends and reproductive parameters of right whales (Eubalaena australis) off Peninsula Valdes, Argentina. Rep. int. Whal. Commn (special issue) 12:271-8.

Rivarola, M.M., Campagna, C. and Tagliorette, A. 1995a. Avistajes de ballenas en el Golfo Nuevo, Argentina. Estudios y Perspectivas en Turismo. Centro de Investigaciones y Estudios Turísticos 4(1):45-57.

Rivarola, M.M., Campagna, C. and Tagliorette, A. 1995b. Impacto del Turismo sobre el comportamiento de la ballena franca austral en el Golfo Nuevo, Argentina. Estudios y Perspectivas en Turismo. Centro de Investigaciones y Estudios Turísticos 4(3):226-42.

Rowntree, V.J., Payne, R.S. and Schell, D.M. 2001. Changing patterns of habitat use by southern right whales (Eubalaena australis) on their nursery ground at Península Valdés, Argentina and in their long-range movements. J. Cetacean Res. Manage. (special issue) 2:133-143.

Watkins, W.A. 1986. Whale reactions to human activities in Cape Cod waters. Mar. Mammal Sci. 2(4):251-62.

Whitehead, H., Payne, R. and Payne, M. 1986. Population estimate for the right whales off Peninsula Valdes, Argentina, 1971-1976. Rep int. Whal. Commn (special issue) 10:169-71. 